\title{
Unsur Kumpulan Cerpen Menghardik Gerimis Karya Sapardi Djoko Damono Sebagai Bahan Pembelajaran
}

\author{
Dede Hikmah $^{1^{*}}$ \\ ${ }^{1}$ Universitas Muhammadiyah Sukabumi, \\ Sukabumi, Jawa Barat, Indonesia \\ *email: dedehykmah61@gmail.com
}

Received: 27 Juli 2020

Accepted: 29 September 2020

Published: 30 September 2020

doi: $10.22236 /$ imajeri.v3i1.5333

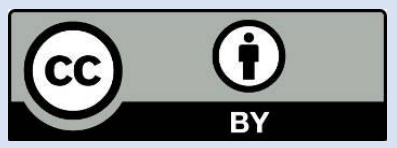

(C) 2020 Oleh authors. Lisensi Imajeri: Jurnal Pendidikan Bahasa dan Sastra Indonesia, Uhamka, Jakarta. Artikel ini bersifat open access yang didistribusikan di bawah syarat dan ketentuan Creative Commons Attribution (CC-BY) license.

(http://creativecommons.org/licenses/by/4.0/).

\begin{abstract}
Abstrak
Unsur cerpen selalu menarik dan unik. Hal inilah yang membuat penelitian tentang unsur cerpen belum berakhir. Selain itu dapat juga dijadikan sebagai bahan pembelajaran alternatif. Oleh karena itu penelitian bertujuan untuk menganalisis unsur pembangun kumpulan cerpen Menghardik Gerimis menjadikan cerpen sebagai bahan ajar untuk siswa SMK kelas XI. Metode yang digunakan ketika penelitian yaitu menggunakan kualitatif deskriptif. Teknik pengumpulan data yang digunakan yaitu: observasi, tes, angket, dan dokumentasi. Hasil analisis yang telah dilakukan mengemukakan bahwa terdapat unsur intrinsik: tema, alur, tokoh dan penokohan dan latar. Selanjutnya unsur ekstrinsik: nilai moral dan nilai sosial yang sesuai dengan silabus kelas XI semester satu dengan standar kompotensi dan kompotensi dasar dalam pembelajaran bahasa Indonesia. ketiga cerpen ini layak di jadikan sebagai bahan ajar pada siswa SMK kelas XI, karena respon peserta didik menunjukan bahwa cerpen yang terdapat dalam buku Menghardik Gerimis karya Sapardi Djoko Damono menarik untuk dibaca dan dijadikan bahan ajar.

Kata kunci: Unsur Intrinsik; Unsur Ekstrinsik; Cerpen; Bahan Ajar
\end{abstract}

\section{Abstract}

Short story elements are always interesting and unique. This is what makes research on short story elements not over. Besides that, it can also be used as an alternative learning material. Therefore, this research aims to analyze the building blocks of the collection of Mengardik Gerimis short stories to make short stories as teaching materials for XI grade students of SMK. The method used when research is using descriptive qualitative. Data collection techniques used are: observation, tests, questionnaires, and documentation. The results of the analysis that have been carried out suggest that there are elements in the short story that can be used as a learning tool in class XI Vocational Schools.

Keywords: Intrinsic element; Extrinsic Elements; Short story; Teaching materials.

\section{PENDAHULUAN}

Sastra dan bahasa saling berkaitan karena bahasa menjadi sarana untuk mewujudkan sastra, baik secara tertulis maupun secara lisan. Karya sastra merupakan sajian yang di dalamnya terdapat nilai-nilai kehidupan yang bisa menjadi contoh untuk pembacanya. Berbicara tentang karya sastra yang bersifat imajinatif, ada tiga genre sastra yaitu prosa, puisi 
dan drama. Prosa merupakan teks jenis fiksi, naratif, atau wacana naratif. Sebagai karya imajinasi, fiksi menggambarkan berbagai permasalahan hidup yang di alami manusia (dirinya sendiri) dan dengan lingkungannya (masyarakat). Anggraini dan Kusniarti (2017) menyatakan bahwa melalui pembelajaran sastra anak dapat mengenal budaya dan aneka nilai di dalamnya.

Adapun salah salah satu teks yang memiliki jenis prosa salah satunya yaitu cerpen atau cerita pendek. Cerpen termasuk salah satu materi pembelajaran sastra yang terdapat dalam silabus bahasa Indonesia dan buku pegangan peserta didik bahasa Indonesia. Cerpen diajarkan dikelas XI dengan kompetensi dasar 3.9 yaitu menganalisis unsur-unsur pembangun cerita pendek dalam buku kumpulan cerita-cerita pendek.Berdasarkan kompetensi 3.9 materi teks cerpen, peserta didik dapat menganalisis unsur-unsur pembangun teks cerpen, pada kompetensi dasar tersebut sebetulnya dapat dipahami dan diselesaikan dengan mudah. Namun, berdasarkan hasil observasi yang dilakukan di SMK Muhammadiyah 1 Kota Sukabumi pada tahun pelajaran 2020/2021 masih terdapat peserta didik yang kesulitan dalam mempelajari unsur-unsur pembangun cerpen. Selain itu, karena teks cerpen yang kurang menarik dan tidak mudah dipahami membuat peserta didik kesulitan dalam mempelajari unsur-unsur pembangun teks cerpen. Dengan demikian, berdasarkan permasalahan tersebut peneliti mencari teks cerpen yang memiliki daya tarik untuk peserta didik, sehingga mudah dipahami sesuai dengan peserta didik ditingkat SMK. Penelitian sebelumnya tentang menganalisis unsur-unsur pembangun cerpen pernah dilakukan oleh Hamdani Kamal Nurjaya (2019) dan Agung Prasetyo (2013).

Berdasarkan dua penelitian sebelumnya, penelitian ini memiliki perbedaan dengan berfokus pada cerpen Untuk Elisa, Menghardik Gerimis, dan Stasiun karya Sapardi Djoko Damono yang dianalisis unsur intrinsik dan ekstrinsik. Unsur intrinsik (tema, alur, tokoh dan penokohan, dan latar) dan Ekstrinsik (nilai moral, dan nilai sosial). Sementara itu, hasil analisis dapat dijadikan sebagai bahan pembelajaran sastra di SMK Muhammadiyah 1 kota Sukabumi.

Nurgiyantoro (dalam Kerti, 2020) mengatakan bahwa cerpen merupakan cerita pendek yang hanya memiliki satu tema, karena berkaitan dengan plot yang tunggal dan memiliki tokoh yang terbatas.Selanjutnya cerpen menurut Hikmat, Solihati, \& Hidayatullah (2017) menyatakan bahwa cerpen adalah cerita fiksi yang disajikan secara singkat dan dapat memberikan kesan tunggal kepada pembacanya. Kemudian menurut Wicaksono (2014) menyatakan bahwa cerpen adalah fiksi singkat dengan pelaku terbatas dan cerita memiliki kesan tunggal.

Cerpen merupakan salah satu cerita bersifat fiksi dan berbentuk prosa. Cerpen memiliki cerita yang singkat, pendek dan unsur ceritanya lebih tertuju pada peristiwa pokok. Selanjutnya jumlah tokoh atau pelaku dalam cerpen terbatas dan isi dari cerita meninggalkan pesan yang di tulis oleh pengarang. Selain itu dilihat dari segi jumlah halaman dan isi dalam cerpen biasanya relatif pendek, singkat, dan mudah untuk di pahami. Pranoto (dalam Syathariah (2011) mengemukakan bahwa cerpen merupakan cerita pendek yang terdiri dari 2000 kata sampai dengan 10.000 kata. Akan tetapi, ada juga cerpen yang hanya terdiri dari 750 kata sampai 1000 kata yaitu cerita mini. Untuk mempermudah pemahaman dalam cerpen, maka diperlukan untuk melakukan analisis terhadap unsur-unsur pembangun yang terdapat dalam cerpen yaitu unsur intrinsik dan ekstrinsik. Unsur intrinsik merupakan unsur yang terdapat pada karya sastra, adapun unsur intrinsik ini terdiri dari tema, alur atau plot, tokoh dan penokohan, latar,gaya bahasa, dan yang terakhir adalah amanat atau pesan yang di tulis pengarang dalam karya sastranya. Dalam mencari atau menganalisis unsur intrinisk pada 
karya sastra, yang harus di lakukan yaitu membaca dan memahami isi karya sastra secara keseluruhan. Karya sastra tidak akan tumbuh sendiri tanpa unsur pembangun, karena ia juga berkaitan dengan unsur ekstrinsik dengan faktor yang ada di luar karya sastra itu sendiri. Adapun unsur ekstrinsik ini terdiri dari latar belakang masyarakat, latar belakang penulis, dan nilai-nilai yang terdapat pada cerpen.

Menurut Warisman (2016) mengatakan bahwa pembelajaran bahasa dan sastra Indonesia di sekolah memiliki peran penting, karena pembelajaran bahasa dan sastra Indonesia menjadi tolak ukur keberhasilan dalam semua bidang studi. Pembelajaran sastra diharapkan dapat membantu peserta didik untuk lebih mengenal dirinya sendirir, budaya, dapat menemukan gagasan dana perasaan serta dapat berpastisipasi dalam masyarakat. Cerpen yang menarik bisa menjadi bahan ajar di sekolah, bahan ajar merupakan perangkat atau alat pembelajaran yang digunakan guru dan disusun secara sistematis dalam kegiatan belajar mengajar. Supriyanto (2018) menyatakan bahwa secara umum bahan ajar di batasi dengan pengertian teks karena bahan ajar sebatas adalah tulisan yang sudah disusun dalam buku. Agar tercapainya tujuan pembelajaran, bahan ajar untuk pembelajaran juga harus memenuhi kriteria bahan ajar, seperti: Selft Intruction, Self Contained,Stand alone,Adaptif, dan User Friendly. Bahan ajar bukan hanya sebagai alat untuk membantu pendidik dalam melaksanakan tugasnya, akan tetapi bahan ajar juga memiliki fungsi. Adapun fungsi dalam bahan ajar menurut Prastowo (2015) terbagi dua, bagi guru dan untuk dan bagi siswa. Fungsi bahan ajar bagi guru yaitu menghemat waktu untuk guru dalam ketika sedang melakukan pembelajaran di kelas, meningkatkan proses pembelajaran dan dijadikan bahan untuk evaluasi dalam menguasai hasil belajar. Selanjutnya fungsi untuk siswa yaitu, siswa dapat belajar sendiri, dapat dilakukan dimana saja, membangun siswa untuk mengembangkan pembelajarannya sesuai minat, dan dapat menjadi sumber belajar tambahan. Awalludin (2017) menyatakan bahwa bahan ajar adalah materi yang akan dikuasai peserta didik dengan susunan yang sistematis dalam rangka mencapai tujuan pembelajaran yang ditentukan.

Dalam memilih bahan ajar, guru harus lebih selektif karena bahan ajar yang baik adalah yang memenuhi prinsip bahan ajar. Adapun prinsip bahan ajar yaitu: Prinsip yang relevasi, prinsip konsistensi, dan prinsip kecukupan. Karya sastra merupakan hasil dari karya seorang penulis baik dari kisah nyata kehidupannya, lingkungan masyarakat atau bisa juga ditulis secara fiksi. Karya sastra yang akan dibahas dalam penelitian ini adalah kumpulan cerpen Menghardik Gerimis karya Sapardi Djoko Damono sebagai bahan pembelajaran di kelas XI SMK Muhammadiyah Kota Sukabumi Tahun Pembelajaran 2020/2021. Cerpen yang dipilih banyak mengandung nilai-nilai kehdiupan salah satunya adalah nilai-nilai yang akan di analisis dalam penelitian yang diakukan. Penelitian yang di lakukan bertujuan untuk: 1) Mengetahui unsur Instrinsik yang terdapat dalam kumpulan cerpen Sapardi Djoko Damono yang berjudul Untuk Elisa, Menghardik Gerimis, dan cerpen yang berjudul Stasiun. 2) Mengetahui unsur ekstrinsik yang terdapat dalam kumpulan cerpen Sapardi Djoko Damono yang berjudul Untuk Elisa, Menghardik Gerimis, dan cerpen yang berjudul Stasiun. 3) Mengetahui, apakah kumpulan cerpen Sapardi Djoko Damono yang berjudul Untuk Elisa, Menghardik Gerimis, dan cerpen yang berjudul Stasiun dapat dijadikan sebagai bahan ajar dikelas XI SMK Muhammadiyah 1 kota Sukabumi. 


\section{METODE}

Penelitian ini menggunakan metode kualitatif. Menurut Rukajat (2018) menyatakan bahwa penelitian kualitatif adalah penelitian yang mengumpulkan laporan dengan cara temuan-temuan peneliti yang tidak berfokus pada perhitungan statistik, atau cara-cara lain yang berhubungan dengan angka. Penelitian kualitatif lebih fokus pada obyek yang sedang di teliti secara mendalam atau secara detail. Selanjutnya menurut Anggito dan Setiawan (2018) menyatakan bahwa penelitian kualitatif adalah jenis penelitian yang mengumpulkan data dengan cara ilmiah dimana peneliti sebagai instrumen kunci, pengambilan sampel sumber data dilakukan secara khusus yan sesuai dengan tujuan penelitian dan mengambil sampel dengan cara tidak sama. Teknik pengumpulan datanya menggunakan trianggulasi (gabungan), analisisnya bersifat kualitatif dan hasilnya lebih menekan pada makna. Dengan demikian, metode penelitian yang digunakan pada penelitian ini adalah metode penelitian kualitatif untuk mendeskripsikan hasil dari analisis unsur intrinsik dan ekstrinsik cerpen yang berjudul Menghardik Gerimis, Untuk Elisa, dan Stasiun karya Sapardi Djoko Damono. Penelitian kualitatif adalah metode penelitian yang mengasilkan data secara deskriptif. Menurut Rukin (2019:6) mengatakan bahwa metode penelitian kualitatif adalah riset yang bersifat deskriptif. Dengan demikian, penelitian ini menggunakan desain penelitian deskriptif analis, guna untuk menganalisis unsur intrinsik dan ekstrinsik cerpen yang berjudul Untuk Elisa, Menghardik Gerimis, dan Stasiun karya Sapardi Djoko Damono kemudian cerpen tersebut akan dibaca, dianalisis, dan diberi kesimpulan. Hasil dari analisis cerpen dalam penelitian ini akan dilakukan uji coba atau uji kelayakan cerpen terhadap siswa kelas XI di SMK Muhammadiyah 1 kota Sukabumi dalam pembelajaran menganalisis unsur intrinsik dan ekstrinsik pada cerpen. Subjek dalam penelitian ini adalah kelas XI SMK Muhammadiyyah 1 kota Sukabumi, sedangkan objek dalam penelitian ini adalah kumpulan cerpen Menghardik Gerimis karya Sapardi Djoko Damono. Cerpen yang telah dipilih kemudian dibaca dan dianalisis unsur intrinsik dan ekstrinsiknya. Setelah itu hasil analisis dijadikan bahan pembelajaran sastra kelas XI SMK Muhammadiyah 1 Kota Sukabumi, yang bertepatan di Jl. Siliwangi No.76, Cikole, Kec. Cikole, Kota Sukabumi, Jawa Barat 43113. Intrumen yang di gunakan dalam penelitian ini meliputi: teks, dan angket. Tes menurut Sudaryono (dalam Teluma dan Rivaie, 2019) berisi pertanyaan yang harus dijawab untuk mengukur kemampuan peserta didik dalam menguasai pelajaran dalam aspek pengetahuan dan keterampilan.

Tes yang digunakan dalam penelitian ini adalah tes secara tertulis. Tes atau soal yang dibuat oleh peneliti berdasarkan KD 3.8 mengidentifikasikan nilai-nilai yang terkandung dalam kumpulan cerpen dan KD 3.9 menganalisis unsur-unsur pembangun cerpen. Sedangkan angket merupakan daftar pertanyaan yang digunakan untuk pengumpulan data yang dilakukan peneliti dengan cara memberi atau menyebarkan pertanyaan secara tertulis kepada responden. Dalam penelitian ini peneliti menyertakan angket yang harus diisi oleh peserta didik. Dalam angket tersebut terdapat 11 pertanyaan yang disesuaikan dengan KD 3.8 mengidentifikasikan nilai-nilai yang terkandung dalam kumpulan cerpen dan KD 3.9 menganalisis unsur-unsur pembangun cerpen.

Teknik pengumpulan data adalah cara untuk mendapatkan data-data agar peneliti dapat menjelaskan permasalahan penelitiannya sebagaimana disebut oleh Sugiyono (dalam Firdaus dan Zamzam, 2018). Teknik pengumpulan data pada penelitian ini yaitu: 1) Observasi, merupakan cara peneliti untuk melihat langsung keadaan atau tempat yang akan menjadi subjek penelitian. Observasi menurut Nawawi dan Martini (dalam Sugiarto, 2015) 
menyatakan bahwa teknik pengumpulan data salah satunya yaitu observasi, dengan cara mengamati dan mencatat unsur-unsur yang ada pada objek penelitian. Dalam penelitian yang dilakukan, peneliti melakukan observasi awal secara langsung ke sekolah yang dijadikan tempat penelitian yaitu di SMK Muhammadiyah 1 kota Sukabumi. Observasi yang digunakan dalam penelitian ini berupa observasi partisipatif, yaitu penulis ikut terjun langsung ke lapangan.Dari observasi partisipatif penulis dapat mengumpulkan data-data seperti photo pada saat penulis sedang melakukan penelitian secara langsung. 2) Tes, tes yang diberikan kepada peserta didik akan berupa essay dan memiliki dua soal. Soal tersebut berhubungan dengan mendeskripsikan atau mengidentifikasi tema,alur, tokoh dan penokohan, dan latar dalam cerpen serta menemukan nilai-nilai dalam cerpen yang diberikan seperti nilai moral dan nilai sosial. Semua soal yang diberikan berdasarkan materi yang telah dipelajari sebelumnya. 3) Angket, dalam penelitian ini angket yang diberikan kepada peserta didik berupa angket check list $(\sqrt{ })$. Angket checklist adalah angket yang menggunakan tanda $(\sqrt{ })$ untuk menjawab pertanyaan pada soal yang diberikan, guna untuk mengetahui tanggapan peserta didik terhadap hasil analisis unsur intrinsik dan ekstrinsik cerpen Menghardik Gerimis, Untuk Elisa dan cerpen yang berjudul Stasiun karya Sapardi Djoko Damono yang menjadi salah satu bahan ajar pembelajaran bahasa Indonesia. 4) Dokumentasi, adapun bentuk dokumentasi dalam penelitian ini seperti gambar dan dokumentasi pendukung pada saat melakukan penelitian di SMK Muhammadiyah 1 kota Sukabumi. Pada tahap dokumentasi peneliti mengumpulkan data informasi berupa gambar dan dokumentasi pendukung pada saat melakukan penelitian di SMK Muhammadiyah 1 kota Sukabumi.

Masuk pada teknik analisis data yang di gunakan yaitu: 1) Data, teori penelitian dan metode yang diambil hanya yang berkaitan dengan analisis unsur intrinsik dan ekstrinsik pada cerpen "Menghardik Gerimis", "Untuk Elisa" dan "Stasiun" karya Sapardi Djoko Damono. 2) Setelah data-data yang dibutuhkan terkumpul peneliti kemudian melakukan analisis unsur intrinsik dan ekstrinsik pada cerpen yang dipilih. kemudian peneliti melakukan pengumpulan data baik berupa data hasil analisis peneliti, kuesioner yang sudah diisi oleh siswa mengenai cerpen Sapardi Djoko Damono dan photo pada saat melakukan kegiatan penelitian. 3) Selanjutnya pada tahap terakhir peneliti mulai membuat simpulan dari hasil analisis yang telah dilakukan sejak penelitian dimulai..

\section{HASIL DAN PEMBAHASAN}

\section{Analisis Unsur Intrinsik Cerpen Menghardik Gerimis Karya Sapardi Djoko Damono}

Tema dalam cerpen Menghardik Gerimis karya Sapardi Djoko Damono adalah tentang seorang laki-laki yang tidak suka terhadap gerimis, karena dalam cerita tersebut menggambarkan sebab dan akibat. Arti dari tema tersebut dapat dilihat pada kutipan-kutipan berikut ini:

"lelaki itu suka hujan, bahkan bisa di katakan mencintai hujan, tetapi menghadapi gerimis ia sama sekali tidak pernah bisa menahan kemarahan. Sudah berulang kali laki istrinya mengingatkan perangai buruk itu, tetapi lakinya sama sekali tidak menggubris. "Biar masuk neraka jahanam gerimis itu!" ujarnya setiap kali mendengar suara rintikrintik di pohonan dan genting" (Damono, 2019).

Berdasarkan kutipan-kutipan di atas menujunkan tokoh utama dalam cerpen tersebut mengungkapkan ketidak sukaannya terhadap gerimis. ketika gerimis mulai datang ia tidak 
bisa menahan amarahnya bahkan ia selalu menghardik gerimis, istrinya selalu mengingatkan ia untuk menahan amarahnya namun ia tidak pernah mendengar nasihat dari istrinya. Dari rasa kesal yang selalu dirasakan menyebabkan rasa dendam yang amat mendalam terhadap gerimis.

Selanjutnya, alur yang terdapat pada cerpen Menghardik Gerimis karya Sapardi Djoko Damono adalah alur maju, yang memiliki lima tahapan yaitu: tahap pengenalan, konfliks, klimaks, antiklimaks, dan penyelesaian. Tahapan-tahapan tersebut dapat dilihat pada kutipan dibawah ini:

"Perempuan cantik itu sama sekali tidak suka kalau suaminya menghardik gerimis. Lelaki itu suka hujan, bahkan bisa dikatakan mencintai hujan, tetapi menghardik gerimis ia sama sekali tidakpernah bisa menahan kemarahan. Sudah berulang kali istrinya mengingatkan perangai buruk itu, tetapi lakinya sama sekali tidak menggubris" (Damono, 2019).

Berdasakan kutipan di atas menunjukkan awal cerita di ceritakan oleh penulis, menceritakan tentang laki-laki yang sangat membenci gerimis. Istrinya sudah berulang kali mengingatkan untuk melawan amarahnya terhadap gerimis, namun suaminya tidak pernah mau mendengar nasihat dari istrinya. Selanjutnya masuk pada tahap kedua yaitu tahap konflik:

tetapi menghardik gerimis ia sama sekali tidak pernah bisa menahan kemarahan. Sudah berulang kali istrinya mengingatkan perangai buruk itu, tetapi lakinya sama sekali tidak menggubris" (Damono, 2019).

Berdasarkan kutipan di atas awal konflik bermula ketika istrinya mengingatkan untuk membuang sifat buruk itu, akan tetapi nasihat istrinya tidak pernah ia dengar. Sementara itu lanjut pada tahapan ketiga yaitu klimakas atau memuncaknya masalah. Klimaks pada cerpen Menghardik Gerimis karya Sapardi Djoko Damono bermula ketika gerimis itu datang. Bisa dilihat pada kutipan dibawah ini:

"Biar masuk neraka gerimis jahanam itu!" ujarnya setiap kali mendengar suara rintikrintik di pohonan dan genting" (Damono, 2019).

Berdasarkan kutipan di atas dapat dilihat bahwa tokoh laki-laki yang membenci gerimis sedang memaki gerimis setiap kali gemiris mulai turun dan suaranya terdengar seperti rintikrintik di pohon dan di genting. Suasanapun semakin memburuk, laki-laki itu mulai mengatakan ketidak sukaannya terhadap gerimis. Dia mengatakan bahwa ketidak sukaannya terhadap gerimis karena gerimis selalu turun secara perlahan, tidak pernah memberi tahu ia terlebih dahulu. Seperti pada kutipan dibawah ini:

"Kalau hujan sekali tidak apa-apa, aku suka," katanya kepada istrinya selalu. "Tetapi gerimis selalu jatuh pelan-pelan, diam-diam, tidak memberi tahu, dan dengan licik membasahi lantai", katanya melanjutkan, "Aku mencintai hujan sebab kalau jatuh 
bilang terus terang dan jelas suaranya, tidak membiarkan aku terpeleset" (Damono, 2019).

Berdasarkan kutipan di atas, bisa dikatakan bahwa tokoh laki-laki sangat kesal sehingga ia membenci gerimis, alsan ia kesal sampai membenci gerimis karena gerimis selalu datang tiba-tiba dan hanya membasahi lantai. Selanjutnya masuk pada tahap ke empat yaitu tahap antiklimaks, tahap antiklimaks pada cerpen Menghardik Gerimis karya Sapardi Djoko Damono bisa dilihat pada kutipan dibawah ini:

"Perempuan cantik yang sedang mengandung tujuh bulan itu terus berusaha memahami tingkah suaminya yang baru saja menjalankan operasi patah tulang gara-gara terpeleset lantai beranda yang basah oleh gerimis. Sekarang sudah bisa jalan, pakai tongkat, sudah bisa kerja lagi, bisa nyopir. Bisa tugas ke luar kota. Namun, dendamnya pada gerimis tak juga reda" (Damono, 2019).

Berdasarkan kutipan di atas, antiklimaks (penurunan konflik) pada saat istrinya selalu memahami tingkah laku suaminya yang selalu menghardik gerimis. Dari ketidak sukaan suaminya terhadap gerimis ada peristiwa yang menjadi alasan mengapa suaminya begitu membenci gerimis, pada suatu hari suaminya pernah jatuh terpeleset karena menginjak lantai yang basah karena gerimis hingga suaminya mengalami patah tulang. Kini suaminya sudah pulih sepeti biasa, akan tetapi kebenciannya terhadap gerimis tidak pernah hilang. Seperti pada kutipan dibawah ini:

"Hari ini lelaki itu membuka pintu depan yang memisahkan ruang tamu dan beranda depan, menyaksikan gerimis dan menghardiknya" (Damono, 2019).

Berdasarkan kutipan di atas, tokoh laki-laki sedang menyaksikan gerimis dan ia tetap menghardiknya, namun berbeda dengan sebelumnya karena ia tidak lagi banyak marahmarah. Kemudian masuk pada tahap terakhir atau tahap kelima yaitu tahap penyelesaian, tahap penyelesaian masalah dalam cerpen Menghardik Gerimis karyaSapardi Djoko Damono bisa dilihat pada kutipan dibawah ini:

"Ketika Suaminya sudah berangkat kerja, gerimis segera reda. Perempuan cantik itu melangkah keluar rumah dan tampak seolahnya ada setetes air sisa gerimis yang tersangkut di ujung rumput, yang ingin sekali cepat-cepat menguap meleset ke langit atau jatuh ke tanah dan diserap akar pohon mangga" (Damono, 2019).

Berdasarkan kutipan di atas, tahap penyelesaian konflik dapat dilihat ketika suaminya sudah berangkat kerja, gerimis menghilang, dan konflikpun telah usai karena gerimis yang di benci laki-laki dalam cerpen tersebut sudah reda.

Tokoh yang terdapat pada cerpen Menghardik Gerimis yaitu tokoh istri dan suami. Tokoh istri dalam cerpen Menghardik Gerimis adalah tokoh yang cantik serta memiliki sifat yang penyabar,pengertian dan bijaksana. Bisa dilihat pada kutipan dibawah ini: 
"Sudah berulang kali istrinya mengingatkanperangai buruk itu, tetapi lainya sama sekali tidak menggubris. Perempuan cantik yang sedang mengandung tujuh bulan itu terus berusaha memahami tingkah laku suaminya yang baru saja menjalani operasi patah tulang gara-gara terpeleset lantai beranda yang basah oleh gerimis" (Damono, 2019).

Berdasarkan kutipan di atas, dapat dilihat bahwa tokoh istri dalam cerpen Menghardik Gerimis bukan hanya terlihat cantik tapi ia juga memiliki watak yang baik yaitu seperti penyabar, pengertian, dan bijaksana dalam menghadapi tingkah laku suaminya.

Selanjutnya tokoh suami dalam cerpen Menghardik Gerimis adalah tokoh yang keras kepala dan memiliki sifat pendendam. Bisa dilihat dalam kutipan dibawah ini:

"Sudah berulang kali istrinya mengingatkanperangai buruk itu tetapi lakinya sama sekali tidak menggubris" (Damono, 2019).

Berdasarkan kutipan di atas, tokoh suami memiliki watak keras kepala. Istrinya selalu berusaha untuk menasihati suaminya, namun nasihat itu tak pernah di dengar oleh suaminya. Selain memiliki sifat keras kepala, ia juga memiliki sifat pendendam. Sifat tersebut bisa di lihat pada kutipan di bawah ini:

"Biar masuk neraka jahanam gerimis itu!" ujarnya setiap kali mendengar suara rintikrintik di pohonan dan genting. (Damono, 2019).

Berdasarkan kutipan di atas, dapat dilihat bahwa tokoh suami memiliki watak pendendam. Karena setiap kali gerimis datang, ia selalu menghardik gerimis dan selalu berkata "Biar masuk neraka jahanam gerimis itu!" ujar nya setiap hari kepada istrinya. Kata tersebut seakan-akan menunjukan bahwa ia benar-benar sangat membenci gerimis.

Adapun latar yang terdapat pada cerpen Menghardik Gerimis yaitu memiliki tiga latar: Latar tempat, latar waktu, dan latar suasana atau sosial. Latar tempat merupakan gambaran atau penjelasan dimana terjadinya konflik itu. Bisa di lihat pada kutipan di bawah ini:

"Perempuan cantik yang sedang mengandung tujuh bulan itu terus berusaha memahami tingkah suaminya yang baru saja menjalankan operasi patah tulang garagara terpeleset lantai beranda yang basah oleh gerimis" (Damono, 2019).

Berdasarkan kutipan di atas, menunjukan bahwa latar tempat yang ada dan digunakan pada cerpen Menghardik Gerimis yaitu di rumah. Setiap konflik yang diceritakan dalam cerpen tersebut tempatnya tetap sama yaitu di rumah. Seperti pada kutipan dibawah ini:

"Hari ini laki-laki itu membuka pintu depan yang memisahklan ruang tamu dan beranda depan, menyaksikan gerimis dan menghardiknya” (Damono, 2019).

Berdasarkan kutipan di atas, dapat di lihat bahwa laki-laki itu sedang membuka pintu depan yang menjadi salah satu bagian dari rumah. Jadi latar tempat pada cerita tersebut yaitu berada di rumah.

\section{Pemanfaatan Hasil Sebagai Bahan Pembelajaran}

Penelitian yang dilakukan pada kelas XI SMK Muhammadiyah 1 Kota Sukabumi berjumlah 29 orang, akan tetapi pada saat melakukan penelitian terdapat 8 orang peserta didik 
yang tidak hadir dengan berbagai alasan seperti: hanphone yang di pakai sedang rusak, kendala kuota, dan kendala lainnya. Sehingga peserta didik yang hadir hanya berjumlah 21 orang.

Hasil analisis peserta didik terhadap cerpen Menghardik Gerimis karya Sapardi Djoko Damono dapat di kategorikan nilai baik dengan rata-rata yang di dapat siswa secara keseluruhan mengenai tema, alur, tokoh dan penokohan, latar, nilai moral dan nilai sosial pada cerpen Menghardik Gerimis yaitu 95,7. Rata-rata nilai pada tema yaitu 20, nilai rata-rata yang di dapat peserta didik mengenai alur yaitu 17,1.Sedangkan nilai rata-rata yang di dapat siswa mengenai analisis tokoh dan penokohan pada cerpen yaitu 20,nilai rata-rata hasil analisis latar yaitu 20, nilai rata-rata pada nilai moral adalah 9,0 dan nilai rata-rata pada analisis nilai sosial pada cerpen Menghardik Gerimis yaitu 9,5. Bisa di lihat dari nilai rata-rata tersebut menunjukan bahwa ada sebagian siswa yang masih sulit dalam menganalisis atau menemukan alur pada cerpen yang berjudul Menghardik Gerimis karya Sapardi Djoko Damono.

Tabel 4.1.2 Persentase Jumlah Siswa Menentukan Unsur Intrinsik dan Ekstrinsik Cerpen Menghardik Gerimis Karya Sapardi Djoko Damono.

\begin{tabular}{c|ccc} 
NO & NILAI & JUMLAH SISWA & PERSENTASE \% \\
\hline $\mathbf{1}$ & 100 & 17 & 80,95 \\
$\mathbf{2}$ & 90 & 0 & 0 \\
$\mathbf{3}$ & 80 & 3 & 11,42 \\
$\mathbf{4}$ & 70 & 1 & 3,33 \\
$\mathbf{5}$ & 60 & 0 & 0 \\
$\mathbf{6}$ & 50 & 0 & 0
\end{tabular}

Data pada tabel di atas, menyatakan bahwa dari 21 orang siswa yang melakukan analisis unsur intrinsik dan ekstrinsik pada cerpen Menghardik Gerimis karya Sapardi Djoko Damono di dapatkan dengan hasil nilai 100 berjumlah 17 orang dengan persentase nilai 80\%, selanjutnya siswa dengan nilai 80 berjumlah 3 orang dengan persentase $11 \%$ dan siswa yang memiliki nilai 70 berjumlah 1 orang dengan persentase $3 \%$.

Selain menilai hasil analisis yang di lakukan peserta didik, peneliti juga ingin mengetahui respon peserta didik setelah membaca dan menganalisis unsur intrinsik dan ekstrinsik cerpen yang telah meraka laksanakan. oleh karena itu, peneliti memberikan angket respon peserta didik. Angket ini berupa uraian yang berisi 11 pertatanyaan dengan pilihan YA atau TIDAK.

Tabel 4.2.1

Lembar Angket Respon Siswa

\begin{tabular}{c|ccccc} 
NO & PERTANYAAN & \multicolumn{2}{c}{ PENILAIAN } & JUML & \% \\
\cline { 3 - 5 } & & Ya & Tidak & AH & \\
1 & Apakah kamu suka membaca cerpen? & 20 & 1 & 21 & 95,2
\end{tabular}


2 Apakah kamu pernah membaca kumpulan cerpen Menghardik Gerimis Karya Sapardi Djoko Damono?

3 Apakah tema pada cerpen "Menghardik Gerimis",

"Untuk Elisa" dan "Stasiun" karya Sapardi Djoko

Damono menarik untuk dibaca?

4 Apakah tokoh dan penokohan pada cerpen

"Menghardik Gerimis", "Untuk Elisa" dan "Stasiun" menarik?

5 Apakah latar pada cerpen "Menghardik Gerimis", "Untuk Elisa" dan "Stasiun" menarik untuk kamu baca?

6 Apakah latar pada cerpen "Menghardik Gerimis", "Untuk Elisa" dan "Stasiun" mudah untuk dipahami?

7 Apakah nilai moral pada cepen "Menghardik

Gerimis", "Untuk Elisa" dan "Stasiun" mudah untuk dipahami?

8 Apakah nilai sosial pada cepen "Menghardik untuk dipahami?

9 Apakah pembelajaran menganalisis unsur 21 intrinsik dan ekstrinsik mudah dipahami jika menggunakan cerpen "Menghardik Gerimis", "Untuk Elisa" dan "Stasiun" karya Sapardi Djoko Damono?

10 Saya lebih mudah mengerti tentang unsur intrinsik

11 Saya lebih mudah mengerti tentang unsur $14 \quad 7$ ekstrinsik 
Berdasarkan respon siswa di atas, dapat di lihat bahwa respon peserta didik terhadap kumpulan cerpen Menghardik Gerimis karya Sapardi Djoko Damono dinilai positif terhadap pembelajaran analisis unsur pembangun cerpen. Data pada tabel di atas, terbagi kedalam 11 pertanyaa. Pada pertanyaan pertama peserta didik banyak menjawab YA berjumlah jumlah 20 orang dengan persentase angket secara keseluruhan yaitu: $82,5 \%$.

Untuk guru, dapat di jadikan sebagai salah satu contoh dalam pembelajaran analisis unsur intrinsik dan ekstrinsik karya sastra terutama karya sastra cerpen.Untuk sekolah, penelitian ini dapat dijadikan sebagai salah satu referensi bahan pembelajaran sastra terutama pembelajaran menganalisis unsur intrinsik dan ekstrinsik.

\section{KESIMPULAN}

Berdasarkan analisis yang yang dilakukan dapat disimpulkan hal berikut, pertama, peneliti pada cerpen Menghardik Gerimis, Untuk Elisa, dan Stasiun karya Sapardi Djoko Damono terdapat unsur intrinsik dan ekstrinsik. Unsur intrinsik yang di analisis meliputi: tema, alur, tokoh dan penokohan, dan latar. Sedangkan unsur ekstrinsik yang di analisis meliputi: nilai moral dan nilai sosial.Kedua, berdasarkan hasil analisis yang dilakukan peserta didik kelas XI OTKP SMK Muhammadiyah 1 kota Sukabumi terhadap analisis unsur intrinsik dan ekstrinsik pada cerpen yang memiliki judul Menghardik Gerimis, Untuk Elisa, dan Stasiunkarya Sapardi Djoko Damono, di peroleh nilai rata-rata pada setiap cerpen terbilang baik, salah satunya nilai rata-rata keseluruhan yang di peroleh siswa terhadap analisis unsur intrinsik dan ekstrinsik pada cerpen Menghardik Gerimis yaitu 95,7 dengan siswa yang hadir berjumlah 21 orang secara daring.

Berdasarkan hasil angket yang telah di berikan kepada peserta didik secara keseluruhan menjawab "YA" sebanyak 82\% dan tergolong positif. Dengan demikian, dapat di simpulkan bahwa ketiga cerpen yang berjudul Menghardik Gerimis, Untuk Elisa, dan Stasiunkarya Sapardi Djoko Damono, dapat di jadikan sebagai bahan pembelajaran di sekolah. Selanjutnya berdasarkan hasil analisis yang telah di lakukan, terdapat beberapa saran yang berhubungan dengan pembelajaran analisis unsur intrinsik dan ekstrinsik di sekolah. Untuk siswa, dengan adanya penelitian ini, siswa mengetahui kemampuannya terhadap menganalisis unsur instrinsik dan ekstrinsik pada cerpen. Manfaat penelitian ini juga dapat meningkatkan pengetahuan siswa terhadap pembelajaran sebuah cerpen yang ada di sekolah, sehingga ketika mendapat tugas mengenai analisis unsur intrinsik dan ekstrinsik siswa tidak sulit dalam menganalisisnya.

\section{DAFTAR PUSTAKA}

Anggito A., Setiawan, J. (2018). Metodologi Penelitian Kualitatif. Sukabumi: CV. Jejak.

Anggraini, T. K. (2017). Pembelajaran Sastra Indonesia Berbasis Kearifan Lokal. Malang: UMM Press.

Awalludin. (2017). Pengembangan Buku Teks Sintaksis Bahasa Indonesia. Yogyakarta: Deepublish.

Damono, S. D. (2019). Menghardik Gerimis. Jakarta: PT. Gramedia Pustaka Utama.

Firdaus, F. Z. (2018). Aplikasi Metodologi Penelitian. Yogyakarta: Deepublish.

Kerti, I. W. (2020). Mengenali dan Menuliskan Ide Menjadi Cerpen. Bali: Surya Dewata (SD).

Prastowo, A. (2015). Menyusun Rencana Pelaksanaan Pembelajaran (RPP) Tematik Terpadu Implementasi Kurikulum 2013 Untuk SD/MI. Jakarta: Kencana. 
Rukajat, A. (2018). Penerbitan Penelitian Kualitatif (Qualitative Research Aproach). Yogyakarta: Deepublish.

Rukin. (2019). Metodologi Penelitian Kualitatif. Takalar: Yayasan Ahmar Cendikia Indonesia.

Sugiarto, E. (2015). Menyusun Proposal Penelitian Kualitatif. Yogyakarta: Suaka Media.

Sugiarto, E. (2015). Menyusun Proposal Penelitian Kualitatif. Yogyakarta: Suaka Media.

Suprianto, E. (2018). Desain Kurikulum Berbasis SKS dan Pembelajaran Untuk Sekolah Masa Depan. Surakarta: Muhammadiyah University Press.

Syathariah, S. (2011). Estafet Writting (Menulis Berantai) Solusi Dalam Menulis Cerpen Bagi Siswa SMA/MA. Yogyakarta: Leutika.

Teluma, M., \& Rivaie, W.( 2019). Penilain Pembelajaran. Pontianak: PGRI Prov Kallbar.

Wicaksono, A. (2014). Menulis Kreatif Sastra dan Beberapa Model Pembelajarannya. Yogyakarta: Garudhawaca.

Hikmat, A. Solihat, N., \& Hidayatullah, S. (2017). Teori Sastra: Pengantar Kesusastraan Indonesia. Jakarta: Uhamka Press. 